\title{
4 Gene Expression and Tracer-Based Metabolic Flux Analysis 5 Reveals Tissue-Specific Metabolic Scaling in vitro, ex vivo, and in vivo
}

7
Ngozi D. Akingbesote ${ }^{1,2 *}$, Brooks P. Leitner ${ }^{1,2 *}$, Daniel G. Jovin ${ }^{1,2}$, Reina Desrouleaux ${ }^{1,3}$, Wanling Zhu' ${ }^{1,2}$, Zongyu $\mathrm{Li}^{1,2}$, Michael N. Pollak ${ }^{4,5}$, and Rachel J. Perry ${ }^{1,2+}$

*Equal contributions

Departments of ${ }^{1}$ Cellular \& Molecular Physiology, ${ }^{2}$ Internal Medicine - Endocrinology, and ${ }^{3}$ Comparative Medicine, Yale School of Medicine, New Haven, CT 06510

${ }^{4}$ Lady Davis Institute for Medical Research, Jewish General Hospital, Montreal, QC, Canada ${ }^{5}$ Department of Oncology, McGill University, Montreal, QC, Canada

+To whom correspondence should be addressed: rachel.perry@yale.edu

\section{Abstract}

Metabolic scaling, the inverse correlation of metabolic rates to body mass, has been appreciated for more than 80 years. Studies of metabolic scaling have almost exclusively been restricted to mathematical modeling of oxygen consumption. The possibility that other metabolic processes scale with body size has not been studied. To address this gap in knowledge, we employed a systems approach spanning from transcriptomics to in vitro and in vivo tracer-based flux. Gene expression in livers of five species spanning a 30,000-fold range in mass revealed differential expression of genes related to cytosolic and mitochondrial metabolic processes, in addition to detoxication of oxidative damage. This suggests that transcriptional scaling of damage control mechanisms accommodates increased oxidative metabolism in smaller 
species. To determine whether flux through key implicated metabolic pathways scaled, we applied stable isotope tracer methodology to study multiple cellular compartments, tissues, and species. Comparing mice and rats, we demonstrate that while scaling of metabolic fluxes is not observed in the cell-autonomous setting, it is present in liver slices and in vivo. Together, these data reveal that metabolic scaling extends beyond oxygen consumption to numerous other metabolic pathways, and is likely regulated at the level of gene expression and substrate supply.

\section{Introduction}

In 1932, Max Kleiber published a seminal study (Kleiber, 1932), integrating prior reports demonstrating a phenomenon that came to be termed "Kleiber's law," or the principle of metabolic scaling. Metabolic scaling refers to the phenomenon that the metabolic rates of many animals, if not all, scale inversely to three-quarters of their body mass (West et al., 1997). In simpler terms, there is a reduction in metabolic rate as body size increases. For example, an elephant is 25 million times larger than a fruit fly, yet its energy expenditure is only 20 thousand times higher; thus, from fruit fly to elephant, the metabolic rate per gram of body weight scales down 1,250 times. Many hypotheses have been proposed to explain the source of this phenomenon. These hypotheses can be divided into two categories: the first is based on the internal determinants of metabolic rate - based on the animal's internal physical constraints such as the fractal transportation that determines nutrient and oxygen supply (Darveau et al., 2002) and utilization (Darveau et al., 2005) rates across the animal's body surfaces and internal organs (Savage et al., 2007; Thommen et al., n.d.; West et al., 1997), and the second

52 emphasizes the external determinants of metabolic rate - based on ecological restraints on metabolism, such as the optimization of reproductive success based on size-specific rates of survival, which increases markedly in larger animals as compared to smaller (Thommen et al., 
n.d.). However, these hypotheses have been derived almost exclusively from observations of caloric intake and oxygen consumption, with gene expression, and substrate fluxes including

57 lipolysis, gluconeogenesis, and substrate contributions to mitochondrial oxidation almost entirely unexplored.

The theory of hierarchical regulation, that is that gene expression initiates the cascade that allows for flux of metabolic pathways,(Rossell et al., 2005; Suarez and Moyes, 2012) provides a systems framework to understand scaling. Due to the relatively recent advances in high throughput mRNA sequencing and bioinformatics tools that allow for intra-specific data preprocessing (Bray et al., 2016; Conesa et al., 2016; Ritchie et al., 2015), we searched for a set of genes whose expression follows the pattern of metabolic scaling in the liver, the metabolic hub of mammals. Since at basal levels, gene expression of metabolic genes closely approximates protein levels (Schwanhäusser et al., 2011), we hypothesized that genes related to the regulation of oxygen consumption and substrate metabolism may scale, and thus provide a mechanistic transcriptional basis for metabolic scaling across five species: mice (mus musculus), rats (rattus norvegicus), monkeys (macaca mulatta), humans (homo sapiens), and cattle (bos taurus), species with a 30,000-fold range of average body weight in adults (from $30 \mathrm{~g}$

72 in mice, to $900 \mathrm{~kg}$ in cattle). Numerous metabolic genes related to glycolysis, gluconeogenesis,

73 fatty acid metabolism, oxygen consumption, electron transport, and redox function, and detoxification of oxidative damage, followed the pattern of metabolic scaling, and informed our isotope-tracer based in vitro and in vivo metabolic flux studies.

77 To determine if gene expression would correlate with metabolic flux, and therefore a mechanistic read out of metabolic enzyme function, the phenomenon of metabolic scaling our 
lab generated a comprehensive assessment of liver metabolism in vivo and in vitro using modified Positional Isotopomer NMR Tracer Analysis (PINTA) (Perry et al., 2017b) and stable isotope-derived turnover (Perry et al., 2015) methods to measure mitochondrial oxidation of glucose and fatty acids, gluconeogenesis from pyruvate and glycerol, and white adipose tissue lipolysis in rats and mice at multiple nodes of complexity: in vitro in hepatocytes; ex vivo in liver slices comprised of hepatocytes plus the surrounding stellate, Kupffer, and sinusoidal endothelial cells; and in vivo in conscious mice. Our analysis shows that rats exhibit lower metabolic rates when compared to mice in and ex vivo; however, no significant differences were observed when we isolated hepatocytes and cultured them in vitro under identical conditions. Taken together, this study demonstrates systems regulation of metabolic scaling: gene expression in livers showed that scaling occurs to regulate oxygen consumption and substrate supply, isotope-based tracer studies in mice and rats demonstrated the mechanistic function of these enzymes in vivo which was only apparent in the living organism rather than plated cells. This study provides unique insight into the metabolic scaling at the level of gene expression and metabolic enzyme function.

\section{Results}

\section{Genes that scale within the liver are predominantly metabolic genes}

97 Considering that mRNA expression correlates well with protein expression under basal conditions, especially for metabolic genes (Schwanhäusser et al., 2011), we used mRNA expression as a proxy for the relative abundance of metabolic enzymes. We examined gene expression in livers from mice (mus musculus), rats (rattus norvegicus), monkeys (macaca mulatta), humans (homo sapiens), and cattle (bos taurus). After normalizing for differences in 
of metabolic scaling. Genes that followed the pattern of mouse $>$ rat $>$ monkey $>$ human $>$ cow were predominantly related to metabolic pathways, including pyruvate metabolism, amino acid metabolism, and glucose metabolism (Figure 1A). Genes from this scaling list were further filtered down to genes involved in amino acid, carbohydrate, energy, lipid, vitamin, and TCA cycle metabolism, and demonstrated a range of degrees of scaling, with only TCA cycle genes clustering together (Figure 1B).

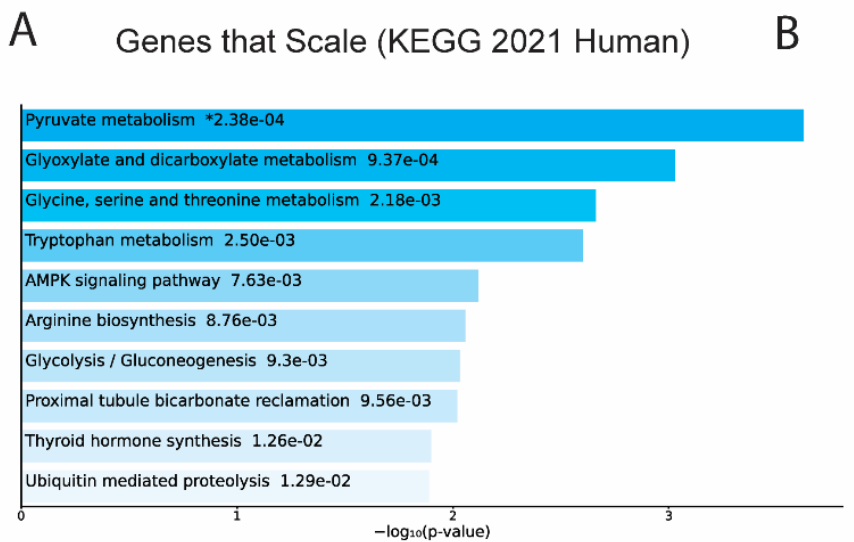

109 metabolism

Metabolic genes that scale in the liver correspond to metabolite detoxification, intertissue metabolism, substrate metabolism, electron transport chain, and NAD

In order to further understand the functional aspects of the metabolic genes that scale, the gene list from Figure 1B was categorized into several functional categories, converging on optimizing energy provision, oxidative metabolism, and damage control from oxidative stress and ammonia (Figure 2). Further, to understand whether or not certain genes that scale were energy 
122

123

124

125

126

127

128

129

130

131

132

133

134

135

136

137

138

139

140

141

142

143

consumers or suppliers themselves, they were further classified into requirements of enzyme action. Eleven of sixteen critical metabolic enzymes that scaled required molecular oxygen, $\mathrm{NAD+} / \mathrm{NADH}$, or ATP/ADP for function, possibly indicating exquisite regulation of energyconsuming processes on the individual gene level. Genes involved in detoxication of lipid peroxidation-derived aldehydes (ALDH7A1), hydrogen peroxide (GPX1), and ammonia (GLUL) suggest scaling of damage control mechanisms that are associated with increased oxidative metabolism across species (Figure 2A). Scaling of genes that are associated with interorgan crosstalk provide evidence for mechanisms of scaling in vivo, that would not be apparent in plated cells: GPT1, which is involved in recycling skeletal muscle-derived alanine back to glucose through the glucose-alanine cycle (Felig and Wahren, 1971; Petersen et al., 2019), and the adiponectin receptor (ADIPOR1), that binds an adipose tissue-derived hormone, adiponectin, that regulates gluconeogenesis and fatty acid oxidation (Lin and Accili, 2011)

(Figure 2B). Genes involved in fatty acid metabolism included the rate limiting steps of the synthesis of CoA (PANK1), of de novo fatty acid synthesis (ACACA), and of fatty acid elongation (ELOVL2), in addition to oxidation of diacylglycerols (LIPE) (Figure 2C). NAD and ATP-dependent genes involved in glycolysis (PDK1), fructose/glucose metabolism (SORD1), and DLST of the TCA cycle also scaled (Figure 2D-E). Multiple mechanisms are suggested to example oxygen consumption at the level of NAD provision for (via the malate/aspartate shuttle (Williamson et al., 1967) catalyzed by MDH1, and tryptophan catabolism to NAD initiated by TDO2), and function of the electron transport chain (subunits of complex I, NDUFA9, and complex IV, COX8A, which catalyzes oxygen accepting the final electrons of the electron transport chain) (Figure 2F-G) (Martínez-Reyes and Chandel, 2020). 

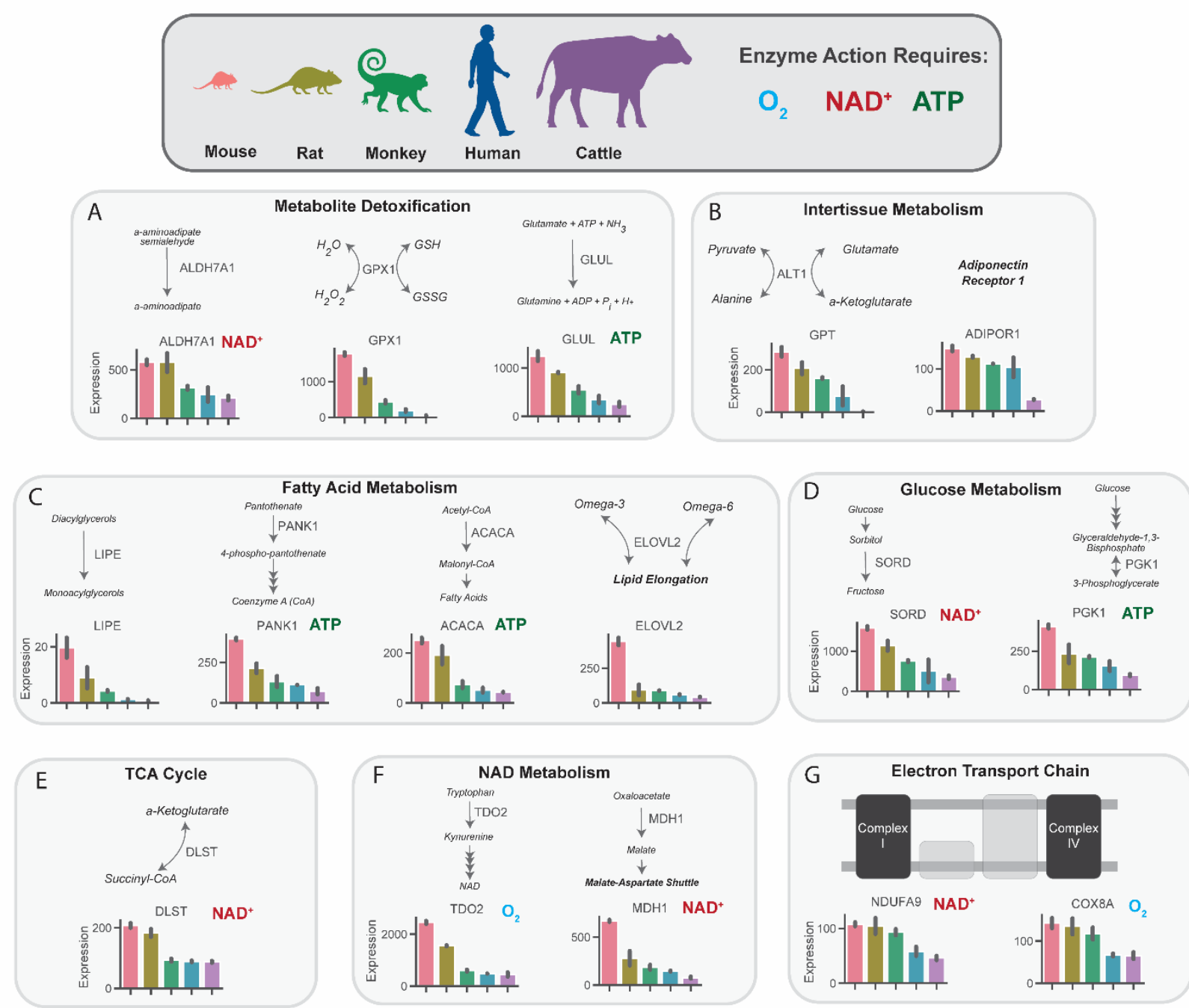

Figure 2. Metabolic genes that scale implicate key pathways in substrate and nucleotide supply, glucose and fatty acid flux, oxygen consumption, and detoxification pathways. mRNA expression of key regulatory genes related to metabolite detoxication (A), intertissue metabolism (B), fatty acid metabolism (C), glucose metabolism (D), tricarboxylic acid (TCA) cycle, NAD metabolism $(F)$, and the electron transport chain $(G)$ in mice, rats, monkeys, humans, and cattle. All genes met an adjusted $p$-value threshold of 0.01 using a one-way ANOVA with the Bonferroni correction for multiple comparisons.

Metabolic rates are not significantly different in vitro in plated hepatocytes from mice as compared to rats

Considering data reporting marked increases in systemic oxygen consumption in smaller as compared to larger animals, we first asked whether these differences were 
157 characteristic of hepatocytes per se or whether in vivo or hepatocyte-extrinsic signals

158 are required. Consistent with the latter possibility, when we incubated plated

159 hepatocytes in $\left[3-{ }^{13} \mathrm{C}\right]$ lactate and used PINTA to assess a broad spectrum of cytosolic

160 and mitochondrial fluxes, we observed no significant differences in any of the fluxes

161 measured in plated hepatocytes: glucose production, $V_{P C}, V_{C S}$, the contribution of

162 glucose or fatty acids to the tricarboxylic acid (TCA) cycle, or lipolysis (Figure 3A-H,

163 Figure S1). Similarly, a mitochondrial stress test in plated hepatocytes revealed no

164 difference in any parameter: neither basal mitochondrial and non-mitochondrial

165 respiration, ATP production, maximal (uncoupled) respiration, spare respiratory

166 capacity, nor proton leak were different between plated hepatocytes from mice and rats

167 (Figure 3I). Previous studies have demonstrated scaling at the in vitro level in cell

168 suspensions only when analyzed immediately after hepatocyte isolation (Porter and

169 Brand, 1995), and have suggested that the phenomenon of scaling gradually

170 disappears around 24-hours post removal (Brown et al., 2007), similar to the conditions

171 in which we performed these studies, though the majority of in vitro studies have also

172 demonstrated an absence of scaling (Glazier, 2015). We extend these results by adding

173 gluconeogenic and lipolytic fluxes in hepatocytes, glucose production in liver slices, and

174 comprehensive flux analysis in vivo. 


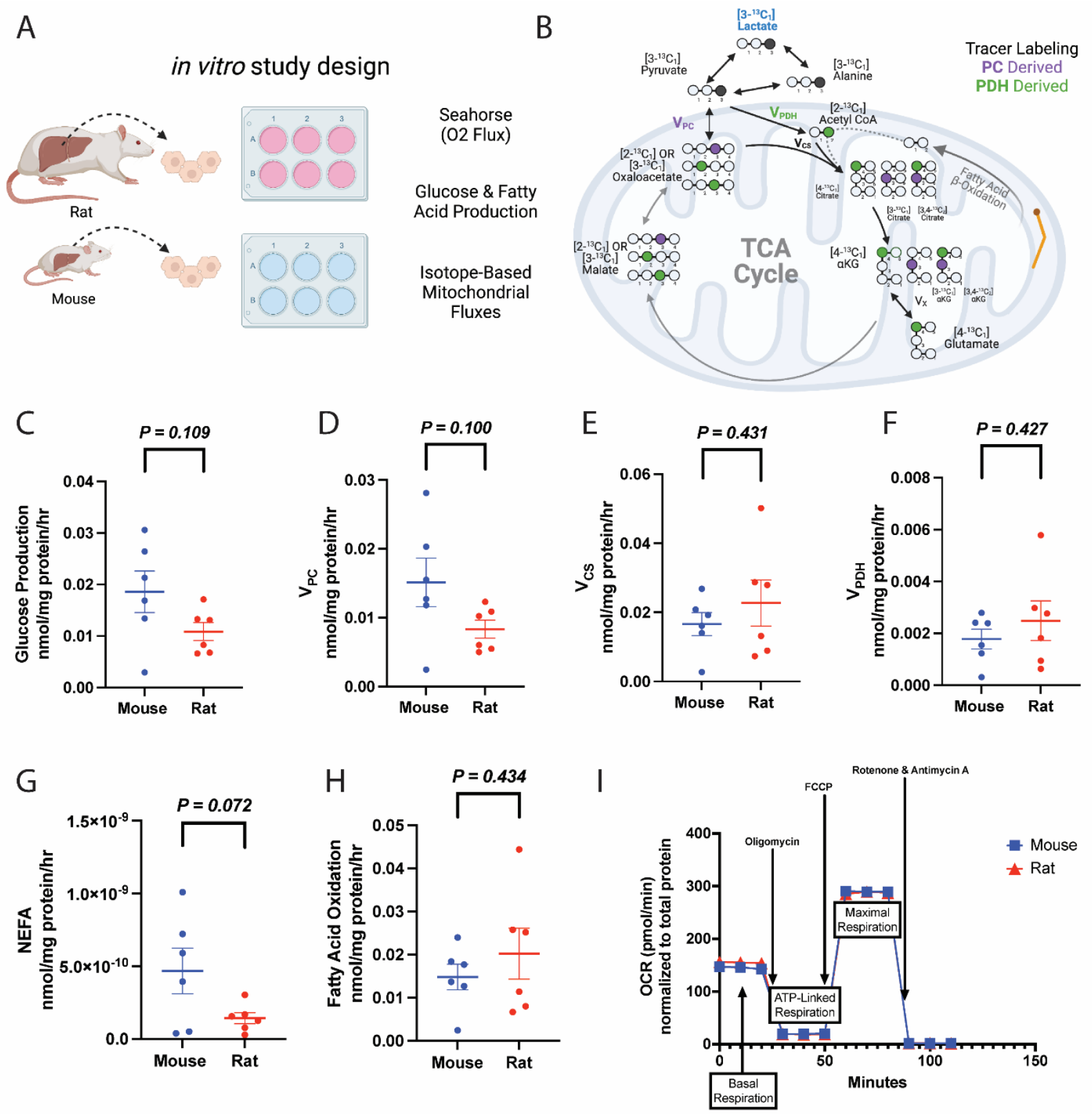

Figure 3. Metabolic fluxes do not scale in vitro in hepatocytes. (A) Study design. This figure was made using Biorender.com. (B) Tracer labeling strategy. (C) Glucose production. (D) Gluconeogenesis from pyruvate (pyruvate carboxylase flux, $\left.V_{P C}\right)$. (E) Citrate synthase flux $\left(V_{C S}\right)$, i.e. mitochondrial oxidation. $(F)$ Pyruvate dehydrogenase flux $\left(\mathrm{V}_{\mathrm{PDH}}\right)$, i.e. the contribution of glucose via glycolysis to total mitochondrial oxidation. (G) Non-esterified fatty acid (NEFA) production. $(\mathrm{H})$ The contribution of fatty acid oxidation to citrate synthase flux. (I) Oxygen consumption rate (OCR) during a mitochondrial stress test. In all panels, groups were compared using the 2-tailed unpaired Student's t-test. No significant differences were observed. 


\section{Glucose production increases ex vivo in liver slices in mice relative to rats}

187 Next, considering that hepatocytes comprise approximately $70-80 \%$ of liver mass and that their isolation and culture in vitro does not replicate in vivo conditions (Krebs, 1950), we asked whether glucose production would scale between mice and rats. Indeed, we found that liver glucose production was three-fold greater in mouse liver slices as compared to rat (Figure 4Aextrinsic signals are involved in liver metabolic scaling.
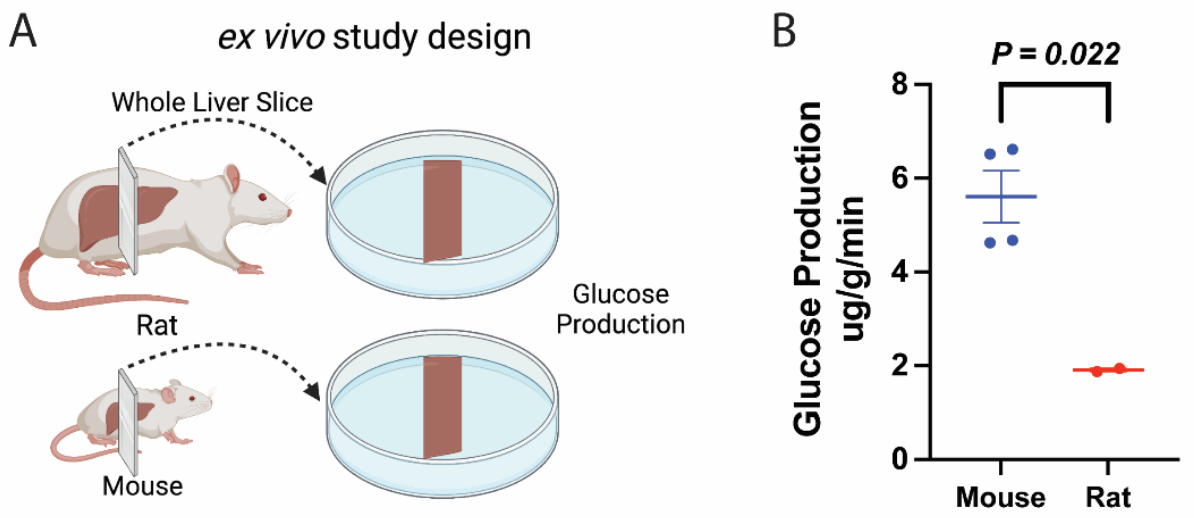

193

194 195 196 197 198

201

Figure 4. Glucose production scales ex vivo in liver slices. (A) Study design. This figure was made using Biorender.com. (B) Glucose production. Groups were compared by the 2-tailed unpaired Student's t-test.

\section{Metabolic rates in multiple tissue types are higher in vivo in mice relative to rats}

We utilized multimodal stable isotope metabolic flux analysis to examine a comprehensive panel of metabolic flux rates in mice and rats (Figure 5A). Using PINTA, we found that both endogenous glucose production and gluconeogenesis from pyruvate (pyruvate carboxylase flux, $\mathrm{V}_{\mathrm{PC}}$ ) per gram liver were more than twofold higher in mice than rats (Figure 5B-C), although the fractional contribution of pyruvate to gluconeogenesis did not differ between mice and rats.

Mitochondrial oxidation scaled similarly, increasing threefold in mice as compared to rats studied under the same conditions, due to increases in both glucose oxidation (pyruvate 
bioRxiv preprint doi: https://doi.org/10.1101/2022.03.02.482685; this version posted March 4 2022. The copyright holder for this preprint (which was not certified by peer review) is the author/funder, who has granted bioRxiv a license to display the preprint in perpetuity. It is made available under aCC-BY-NC-ND 4.0 International license.

206

207

208

209

210

211

212

213

214

215

A
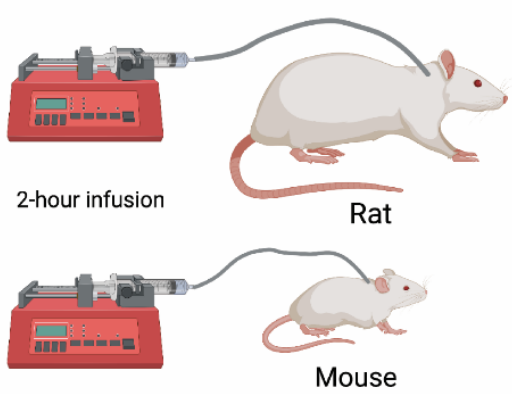

D

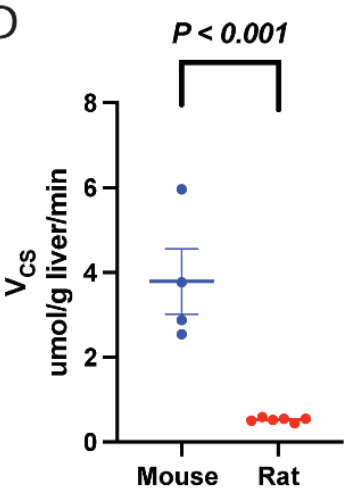

E

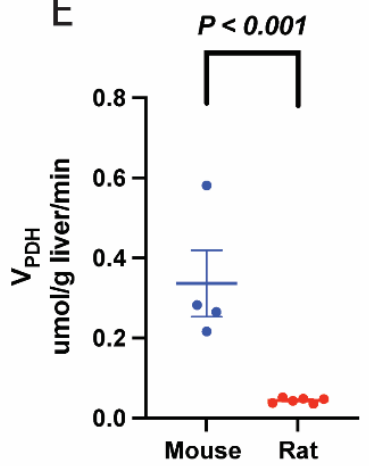

B

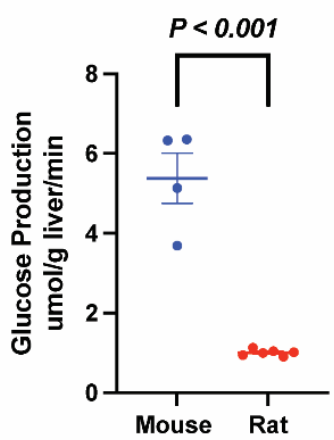

F

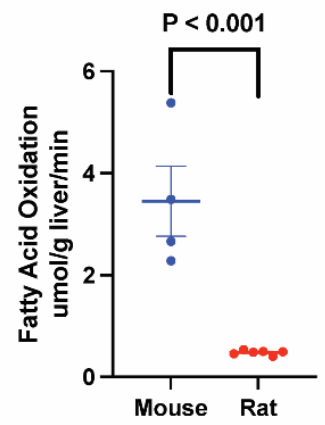

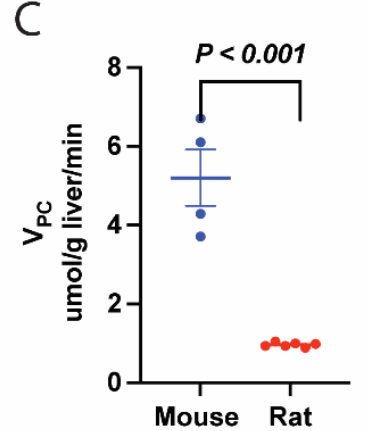

G

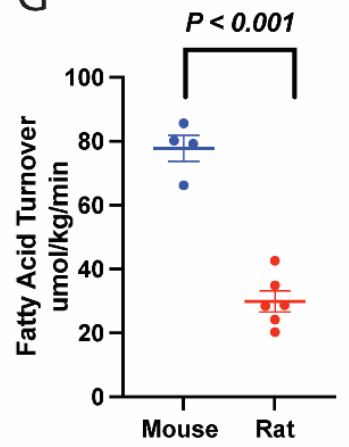

216

217

218

219

220

221

222

Figure 5. A comprehensive analysis of systemic metabolic fluxes reveals in vivo scaling in mice versus rats. (A) Study design. (B) Endogenous glucose production. (C) Gluconeogenesis from pyruvate $\left(V_{P C}\right)$. (D) $V_{C S}$, i.e. mitochondrial oxidation. (E) $V_{P D H}$, i.e. the contribution of glucose via glycolysis to total mitochondrial oxidation. (F) Palmitate (fatty acid) turnover. (G) The contribution of fatty acid oxidation to citrate synthase flux. In all panels, groups were compared using the 2-tailed unpaired Student's t-test. 
Machine learning defined species-specific clusters based on in vivo metabolic fluxes but not in vitro fluxes.

A clustering dendrogram was applied to our in vitro metabolic scaling data and showed no

A Absence of Metabolic Scaling at Cellular Level
Metabolic Scaling Apparent at Tissue and Organismal Level
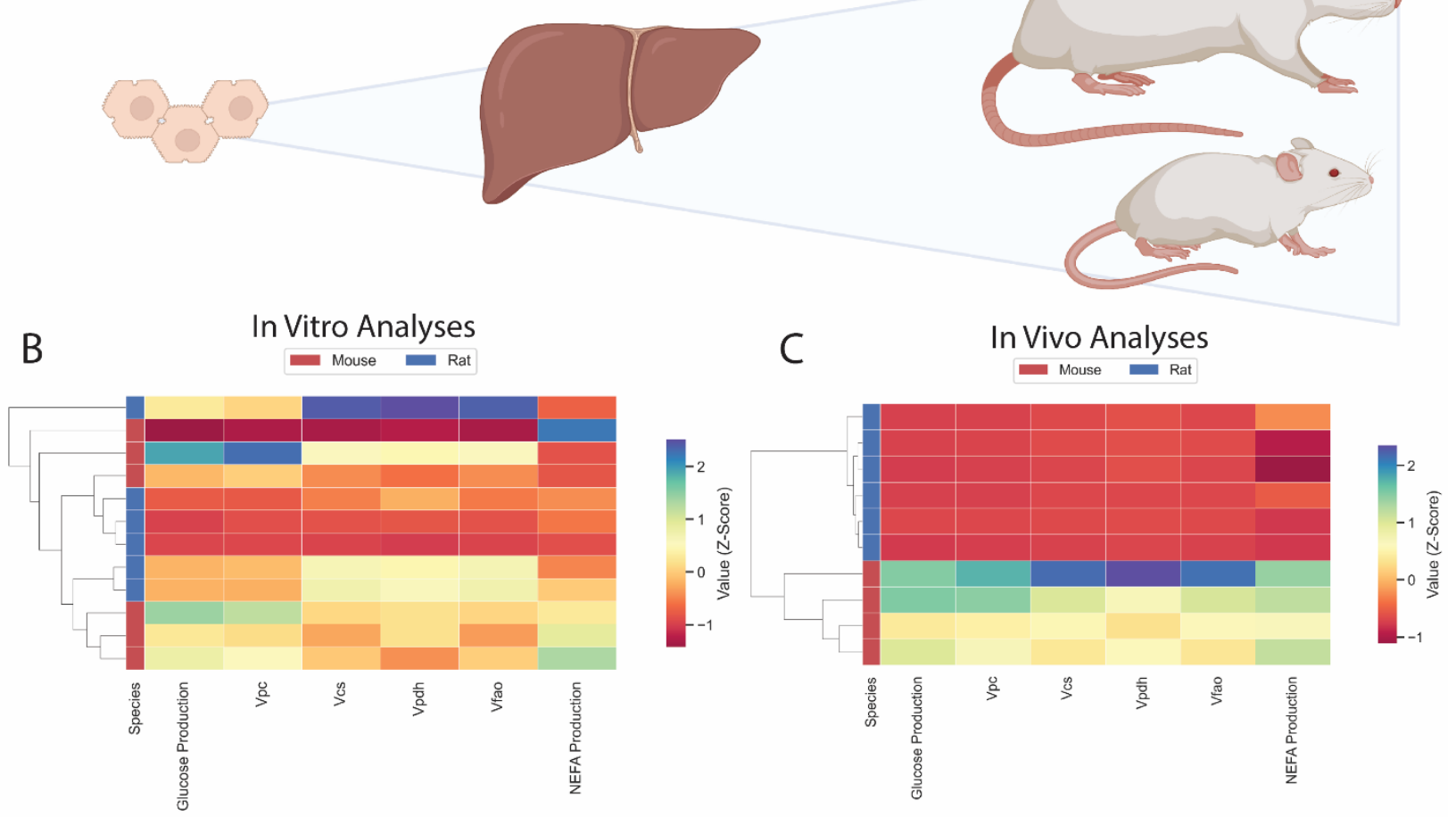

Figure 6. Comparison of in vitro and in vivo results. (A) Study workflow. (B) Clustering heatmap demonstrating the absence of metabolic scaling in vitro. (C) Clustering heatmap demonstrating metabolic scaling in vivo. In panels (B) and (C), mouse and rat color legends correspond to the species label attached to the dendrogram on the leftmost of each graph. Vpc $=$ pyruvate carboxylase flux, $\mathrm{Vcs}=$ citrate synthase flux, $\mathrm{Vpdh}=$ pyruvate dehydrogenase flux, $\mathrm{Vfao}=$ fatty acid oxidation, NEFA $=$ non-esterified fatty acid concentrations. 


\section{Discussion}

Oxygen consumption has been shown to scale inversely with body mass in species ranging in mass across 20 orders of magnitude, from $10^{-14}$ to $10^{6}$ grams (Ernest et al., 2003; Gillooly et al., 2001; Kleiber, 1932; Anastassia M Makarieva et al., 2005; Makarieva et al., 2008; Savage et al., 2004; West et al., 2002). This is perhaps best studied in mammals, but is a highly conserved phenomenon, having also been shown to occur in prokaryotes (Fenchel and Finlay, 1983; A. M. Makarieva et al., 2005; Anastassia M Makarieva et al., 2005; Makarieva et al., 2008; Moses et al., 2008), plants (A. M. Makarieva et al., 2005; Mori et al., 2010; Reich et al., 2006), insects (Chown et al., 2007; Maino and Kearney, 2014; A. M. Makarieva et al., 2005), fish (Clarke and Johnston, 1999; Gjoni et al., 2020; Rubalcaba et al., 2020), and birds (Glazier, 2008; Hudson et al., 2013; A. M. Makarieva et al., 2005). However, a major limitation of prior studies in this field has been that observations have been largely limited to oxygen consumption and caloric intake, leaving other metabolic processes unexplored. While oxygen consumption - reflecting mitochondrial oxidation of carbohydrates and/or fatty acids - is a crucial process for energy generation and reflects the steady-state basal metabolic rate, relying only on this variable, is a crude approach to examine metabolism and can fail to detect differences in substrate contributions to mitochondrial oxidation and cytosolic processes such as gluconeogenesis, in addition to the genes that set the capacity for these processes. This study sought to address this issue by examining the generalizability of metabolic scaling.

By combining mRNA expression measurement across a 30,000-fold range in body mass with isotopic tracer techniques to examine metabolic flux rates in vivo, ex vivo, and in vitro in mice and rats, this work provides new insights regarding inter- and intra-species metabolic scaling. Hepatic mitochondrial oxidation and the contributions of glucose and fatty acids to mitochondrial TCA cycle flux scaled similarly to cytosolic gluconeogenesis and white adipose tissue lipolysis in 
vivo, demonstrating systemic conservation of metabolic scaling. These data suggest that metabolic scaling may be subject to systemic signals to coordinate metabolic rates. Consistent with this interpretation is the fact that most metabolic processes tested - mitochondrial

267 oxidation, the contributions of glucose and fatty acids to TCA cycle flux, glucose production, and

268 lipolysis - scaled similarly, despite the different cellular compartments and tissues responsible

269 for these fluxes.

270 Interestingly, the scaling of GPT and ADIPOR1 further suggest that there is dependence on

271 extra-hepatic organs in the scaling of in vivo gluconeogenesis and fatty acid oxidation: that is,

272 skeletal muscle supply of alanine for the liver mediated glucose-alanine cycle and adipose-

273 tissue derived adiponectin signaling. These findings also suggests that the scaling of

274 mitochondrial mass (Porter and Brand, 1995) or mitochondrial proton leak (Porter and Brand, 275 1993) cannot fully explain metabolic scaling.

277 The possibility that gene expression, as reflected by mRNA abundance, may also scale with 278 body mass has not been previously addressed. We observed that expression of key genes in 279 glycolysis, gluconeogenesis, fatty acid metabolism, NAD synthesis and transport, mitochondrial oxygen consumption, in addition to protection from oxidative damage, scales with body mass.

281 More compelling, however, is the fact that those genes for which scaling of expression with 282 body mass is observed, are not randomly distributed across the genome. Rather, the collection 283 of genes that scale is enriched for genes related to metabolic processes, and whose proteins' 284 functions are constrained by supply of substrate, NAD, ATP, or oxygen. The notion that body 285 mass is a variable related to expression level of certain genes has not previously been 286 considered as an aspect of metabolic scaling, and when combined with isotope-based 287 demonstration of flux through these pathways, yields new insight into the systems regulation of 288 scaling. 
It is also informative to consider the settings in which metabolic scaling was not observed

290 (oxygen consumption, mitochondrial oxidation, lipolysis, and glucose production in

291 hepatocytes). The differences between findings in vitro (where mouse and rat hepatocytes

292 showed no significant difference in any cytosolic or mitochondrial flux) and in vivo observations

293 (where livers exhibited robust metabolic scaling, with all fluxes in mice faster than those of rats)

294 were striking, and emphasize the need to employ tracer methods in vivo to generate a

295 comprehensive picture of the physiologic role of metabolic scaling.

296 Our findings emphasize that measurement of oxygen consumption in vitro may fail to detect any

297 influence of scaling processes present in vivo. Glucose production was three-fold higher in

298 mouse liver slices relative to rat liver slices, but did not significantly differ between plated

299 hepatocytes from mice and rats, suggesting a role for extrinsic signals in metabolic scaling.

300 Taken together, the findings of this study show that the phenomenon of metabolic scaling

301 extends to processes beyond oxygen consumption and caloric intake, and are bookended by

302 scaling not only of gene expression, but also of a plethora of cytosolic and mitochondrial fluxes

303 in vivo. The mechanisms underlying the phenomenon remain obscure, and deserve

304 investigation as a fundamental question in biology (Hatton et al., 2019; Kolokotrones et al., 305 2010; White and Seymour, 2003).

\section{Ideas and Speculation}

308 These data have implications for metabolic regulation during hibernation, in which metabolic

309 rates are reproducibly and markedly but reversibly suppressed (Jansen et al., 2021, 2019;

310 Tøien et al., 2011). Metabolic scaling phenomena may also have medical relevance. Recent

311 reports provide data consistent with "Peto's paradox" by showing that cancer is not more 312 prevalent in larger, long-lived organisms than smaller ones (Anastassia M Makarieva et al., 
2005; Vincze et al., 2022), despite the fact that more cells are at risk for transformation, and over longer periods of time. Metabolic scaling provides a potential explanation: the slower rates of metabolic processes (including oxygen consumption) and reduced oxidative damage in larger animals imply lower rates of proliferation and carcinogenic DNA damage, so that while more cells are at risk in large animals, carcinogenesis proceeds more rapidly in smaller ones.

\section{Materials and Methods}

Rodents: Male C57bl/6J mice and Sprague-Dawley rats were obtained at 8 weeks of age from Jackson Laboratories and Charles River Laboratories, respectively, and given ad lib access to regular chow and water. Mice underwent surgery under isoflurane anesthesia to place catheters

323 in the jugular vein (mice) and in both the jugular vein and carotid artery, with the tip of the

324 arterial catheter advanced into the right atrium of the heart. After a week of recovery and 325 confirmation that the animals had regained their pre-surgical body weight and following a 24 326 hour fast, rodents underwent the in vivo tracer studies described below. Rodents used for 327 hepatocyte studies were fed ad lib until isoflurane euthanasia and liver isolation as described in 328 the in vitro studies below.

331 (Brazma et al., 2003), and were all preprocessed using the same methods. Cattle, monkey, and 332 rat were obtained from E-MTAB-4550, mouse from E-MTAB-5166, and human from E-MTAB6814. Two replicates from each species were used. Raw counts from each species were normalized to counts per million (CPM) and were then TMM-normalized to account for differences in sequencing depth as well as transcript length across species and scanners using the $R$ package edgeR (Robinson et al., 2010). All transcript homologues were converted to 
human gene names using ENSEMBL in the biomaRt R package (Durinck et al., 2009). For the analyses in Figure 5, genes were filtered to those that followed the allometric scaling pattern mouse $>$ rat $>$ monkey $>$ human $>$ cattle. This gene list was put into EnrichR and KEGG pathway enrichment analysis was performed (Kuleshov et al., 2016). Genes in this list that

341 followed the scaling pattern were then filtered based on whether they met one of six Reactome

342 metabolic superpathways related to metabolism of amino acids, carbohydrates, energy, lipids,

343 tricarboxylic acid cycle, and vitamin cofactors (Jassal et al., 2020). A clustering heatmap was performed on these genes using the Seaborn Python package (Waskom, 2021). Genes were plotted again upon this map using the Seaborn Python package. To assess for differences in gene expression in genes displayed on the metabolic map, a one-way ANOVA with a Bonferoni correction for multiple comparisons (thus an adjusted $p$-value threshold for this test was 0.01 from 0.05 for significance) using the Python Scipy package (Virtanen et al., 2020).

In Vitro Tracer Analysis: Primary hepatocytes were isolated by the Yale Liver Center's Cell

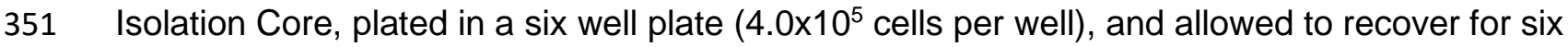

352 hours at $37^{\circ} \mathrm{C}$ in substrate replete media (DMEM high glucose containing $10 \% \mathrm{FBS}, 2 \%$

353 penicillin-streptomycin, $100 \mathrm{nM}$ dexamethasone, $10 \mathrm{mM}$ HEPES, and $1 \mathrm{nM}$ insulin). The

354 attached cells were then washed once in PBS and incubated overnight in low-glucose culture

355 media (DMEM low glucose containing 10\% FBS, 2\% penicillin-streptomycin and $10 \mathrm{mM}$ HEPES) for glucose production assays, or serum-free low-glucose culture medium (DMEM low

357 glucose supplemented with $0.5 \%$ fatty acid free BSA, $2 \%$ penicillin-streptomycin and $10 \mathrm{mM}$ HEPES) for lipolysis assays. Following the overnight incubation, for glucose production assays,

359 cells were washed twice with PBS and the media was replaced with $2 \mathrm{ml}$ of substrate replete glucose production medium (DMEM no-glucose base media containing $0.5 \%$ fatty acid free

361 BSA, $20 \mathrm{mM}$ sodium lactate $\left(50 \% 3^{-13} \mathrm{C}\right), 2 \mathrm{mM}$ sodium pyruvate, $2 \mathrm{mM}$ GlutaMAX, MEM non- 
essential amino acids, and $10 \mathrm{mM}$ HEPES). After a six hour incubation at $37^{\circ} \mathrm{C}$, the media was collected. Glucose concentrations were measured as described in the Biochemical Analysis section, and normalized to total protein measured using the bicinchoninic acid (BCA) assay. For lipolysis assays, cells were washed twice with PBS and the media was replaced with a fresh 2 $\mathrm{ml}$ volume of low-glucose culture medium. Cells were incubated at $37^{\circ} \mathrm{C}$ for six hours, after which the media was collected and non-esterified fatty acid concentrations measured as described in the Biochemical Analysis section. The lipolysis rate was calculated after normalizing to total protein concentrations determined using the BCA assay. Flux ratios were measured using Equations 5-12, and back-calculated from net glucose production determined by measuring the glucose concentration in the media using the Sekisui Glucose Assay and assuming a linear rate of net glucose production during the 6 hour incubation.

Glucose production in liver slices: Mice and rats were fasted overnight (16 hr) and sacrificed. Rodent livers were extracted and washed in Krebs-Henseleit buffer (KHB) containing 550 mM sodium chloride, $23 \mathrm{mM}$ potassium chloride, $6.3 \mathrm{mM}$ calcium dichloride, $10 \mathrm{mM}$ magnesium sulfate, and $6.9 \mathrm{mM}$ sodium phosphate monobasic. Rodent livers were cored into smaller bits using the Alabama R\&D tissue coring press. Cored livers were sliced to the thickness of 230 micron, the lowest setting on the Alabama R\&D tissue slicer. Liver slices were transferred to 24 well plates containing gluconeogenesis media (DMEM without glucose but with $20 \mathrm{mM}$ lactate, 2 mM pyruvate, $10 \mathrm{mM}$ HEPES, and $44 \mathrm{mM}$ sodium bicarbonate) (400 ul for mouse livers and 500 ul for rat livers). The 24 well plates were placed in a tissue culture incubator $\left(5 \% \mathrm{CO}_{2}\right)$ and shaken at 80 RPM for 6 hours. At the end of the $6 \mathrm{hr}$ incubation, liver slices and media were collected. Liver slice weights were measured on a scale. Glucose concentrations from liver slice media were measured using the Sekisui Glucose Assay. Glucose concentrations was normalized to liver weights measured in milligrams and microliters of gluconeogenesis media. 


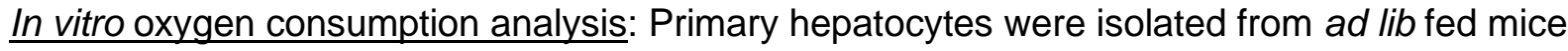
and rats by the Yale Liver Center's Cell Isolation core and plated recovery media as described previously(Camporez et al., 2013) in 24-well XF24 V7 cell culture plates coated with type I collagen. After $6-8$ hours of recovery at $37^{\circ} \mathrm{C}$ in $5 \% \mathrm{CO}_{2}$, cells were washed twice with PBS and the media was replaced with low-glucose culture media (DMEM base medium containing $5 \mathrm{mM}$ glucose, $2 \mathrm{mM}$ glutamine, and non-essential amino acids, $\mathrm{pH} 7.4$ ), in which cells were cultured overnight. The next morning, as we have previously described(Perry et al., 2020), cells were washed twice with PBS and the media was replaced with $500 \mu \mathrm{L}$ XF24 assay medium (DMEM base medium containing $5.5 \mathrm{mM}$ glucose, $1 \mathrm{mM}$ pyruvate, and $2 \mathrm{mM}$ glutamine, $\mathrm{pH} 7.4$ ) and equilibrated at $37^{\circ} \mathrm{C}$ for $60 \mathrm{~min}$. The Seahorse XFe 24 Analyzer was used to perform a mitochondrial stress test: after three baseline measurements of $\mathrm{O}_{2}$ consumption (10 min apart), oligomycin (an inhibitor of ATP synthase) was injected, and three subsequent measures of $\mathrm{O}_{2}$

400 consumption were performed using a $4 \mathrm{~min} \mathrm{mix} / 2 \mathrm{~min}$ wait/4 min measure protocol. Next, the 401 uncoupler 2-[2-[4-(trifluoromethoxy)phenyl]hydrazinylidene]-propanedinitrile (FCCP) was 402 injected to dissipate the proton gradient, with three $\mathrm{O}_{2}$ consumption measurements taken as described above. Finally, rotenone $(0.5 \mu \mathrm{M})$ and antimycin $(10 \mu \mathrm{M})$ were injected to inhibit

404 Complexes I and III, respectively. Oxygen consumption was normalized to total protein measured using the Pierce BCA Protein Assay.

In Vivo Tracer Analysis: Mice and rats received a 3X (5 min) primed-continuous infusion of [3${ }^{13} \mathrm{C}$ ] sodium lactate $(4.5 \mathrm{mg} / \mathrm{kg}$ body weight $/ \mathrm{min}),\left[1,2,3,4,5,6,6-{ }^{2} \mathrm{H}_{7}\right]$ glucose $(1.0 \mathrm{mg} / \mathrm{kg} / \mathrm{min})$, and $\left[\mathrm{U}-{ }^{13} \mathrm{C}_{16}\right]$ potassium palmitate $(0.8 \mathrm{mg} / \mathrm{kg} / \mathrm{min})$ for $120 \mathrm{~min}$. Tracers were infused into the jugular vein (mice) or the right atrium (rats) to ensure systemic delivery. After $120 \mathrm{~min}$, blood 
412 to obtain plasma, then animals were sacrificed with IV pentobarbital and their livers freeze-

413 clamped in liquid nitrogen.

415 Biochemical analysis: In plated hepatocyte and liver slice studies, glucose concentrations in the

416 cell media were determined using the Sekisui Glucose Assay. Non-esterified fatty acid

417 concentrations in the hepatocyte media were measured using the Sekisui Non-Esterified Fatty

418 Acid kit.

419 Glucose production in hepatocytes was determined by measuring the glucose concentration in

420 media after $6 \mathrm{hr}$ of incubation. Glucose enrichment in hepatocytes, plasma, and livers was

421 measured by gas chromatography/mass spectrometry (GC/MS). Samples were deprotonized

422 using 1:1 barium hydroxide:zinc sulfate $(100 \mu \mathrm{l}$ for cells and $300 \mu \mathrm{l}$ for 100 mg liver samples,

423 which were subsequently homogenized using a TissueLyser) and derivatized with $50 \mu$ l:1

424 acetic anhydride:pyridine. After 20 min heating to $65^{\circ} \mathrm{C}, 50 \mu$ methanol was added, and glucose

425 enrichment $\left(\left[{ }^{13} \mathrm{C}_{1}\right],\left[{ }^{13} \mathrm{C}_{2}\right]\right.$ and, in plasma, $\left[{ }^{2} \mathrm{H}_{7}\right]$ (all using the Chemical lonization mode), $[4,5,6-$

$\left.426{ }^{13} \mathrm{C}_{1}\right]$ and $\left[4,5,6-{ }^{13} \mathrm{C}_{2}\right]$ (both using the electron ionization mode)) were measured by GC/MS.

$427\left[{ }^{13} \mathrm{C}\right]$ alanine enrichment was measured by GC/MS (Perry et al., 2016). We have previously 428 shown that flux through pyruvate kinase and malic enzyme - which would add $\left[{ }^{13} \mathrm{C}\right]$ label to 429 carbon 2 of alanine - is minimal under fasting conditions in normal rats (Perry et al., 2016); 430 therefore, the measured $\left[{ }^{13} \mathrm{C}\right]$ alanine enrichment can be attributed entirely to $\left[3-{ }^{13} \mathrm{C}\right]$ lactate 431 enrichment. $\left[{ }^{13} \mathrm{C}\right]$ malate enrichment was also measured by GC/MS (Perry et al., 2017b). Total

432 malate enrichment and $\mathrm{C} 1 \mathrm{C} 2 \mathrm{C} 3$ malate enrichment were measured and the $\mathrm{C} 2+\mathrm{C} 3$ malate 433 enrichment was determined according to Table S1, equations 1 and 2, which relies on the 434 assumption that the $\mathrm{C} 4$ enrichment is approximately equal to the $\mathrm{C} 1$ enrichment of malate 435 (Perry et al., 2017b). Total and C4C5 glutamate enrichment was measured by LC-MS/MS 
436 (Perry et al., 2018). With ${ }^{13} \mathrm{C}$ lactate infusion, no label enters glutamate carbon 5, so all label in

437 the C4C5 fragment was assumed to be label in glutamate C4.

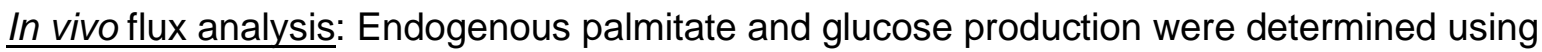

441 enrichment, measured using gas chromatography/mass spectrometry (GC/MS) as described in

442 the Biochemical Analysis section. In the fasted/substrate depleted and therefore glycogen-

443 depleted state (Perry et al., 2018), endogenous glucose production can be attributed entirely to

444 gluconeogenesis (equation 4). Based on equations previously described (Perry et al., 2017b),

445 and after verifying minimal renal and hepatic bicarbonate enrichment by GC/MS (Perry et al.,

$4462020,2017 b)$, we measured the whole-body ratio of phosphoenolpyruvate carboxykinase

447 (PEPCK) flux (i.e. gluconeogenesis from pyruvate) to total gluconeogenesis by mass

448 isotopomer distribution analysis (equations 5 and 6 ), correcting for any $\left[{ }^{13} \mathrm{C}_{2}\right]$ glucose

449 synthesized from $\left[{ }^{13} \mathrm{C}_{2}\right]$ trioses (equation 7). At steady state, $\mathrm{V}_{\text {PEPCK }}$ is equal to the sum of

450 pyruvate kinase flux and pyruvate carboxylase flux $\left(\mathrm{V}_{\mathrm{PK}}+\mathrm{V}_{\mathrm{PC}}\right)$; based on our previously

451 published data, under fasting conditions pyruvate kinase flux is minimal, less than $10 \%$ of

452 pyruvate carboxylase flux (Perry et al., 2016). Therefore, we can assume that the rate of

453 gluconeogenesis from pyruvate (i.e. $V_{\text {PEPCK }}$ ) is approximately equal to $V_{P C}$.

455 Next, we measured the ratio of pyruvate carboxylase anaplerosis to citrate synthase flux

$456\left(\mathrm{~V}_{\mathrm{PC}} / \mathrm{V}_{\mathrm{CS}}\right)$ using the enrichment of liver alanine, malate, and glutamate (equation 8). This

457 equation, in which pyruvate cycling is again assumed minimal, is derived in detail in our recent 458 publication (Perry et al., 2017b). 
460 We measured the fractional contribution of glycolytic carbons to the TCA cycle (i.e. pyruvate

461 dehydrogenase flux relative to citrate synthase flux, $\mathrm{V}_{\mathrm{PDH}} / \mathrm{V}_{\mathrm{CS}}$ ) (equation 9) using the model and

462 assumptions we (Befroy et al., 2014; Perry et al., 2018, 2016; Song et al., 2020) and others

463 (Alves et al., 2011; Petersen et al., 2016, 2015) have described. Finally, absolute turnover rates

464 (equations 10-13) were determined, utilizing the ratios measured with equations 5, 8, and 9, and 465 the absolute gluconeogenesis rate measured using equations 3 and 4.

467 Statistical considerations, power calculations, and statistical analysis: The sample size $(n=4-6$ in 468 vitro replicates or animals in vivo) was calculated to supply $80 \%$ power at $\alpha=0.05$ to detect the 469 expected two-fold difference with 50\% variance. Power calculations were performed using the 470 ClinCalc online calculator. The in vivo studies compared 4-6 biological replicates (unique

471 animals), the liver slice studies compared 2-4 biological replicates, and the in vitro studies

472 compared 2 biological replicates, with 3 technical replicates (separate wells) from each.

473 Rodents were excluded from analysis following tracer studies if they failed to respond

474 immediately (i.e. immediate euthanasia, within 3 seconds) to IV pentobarbital. No samples were 475 excluded from analysis in the in vitro or ex vivo studies. Randomization was not possible during 476 the in vivo studies because of the readily apparent differences between mice and rats, but all 477 analyses were performed by investigators who were blinded as to species.

\section{Acknowledgments}

480 The authors thank Traci LaMoia for her assistance in performing the liver slice experiments,

481 Kathy Harry of the Yale Liver Center for isolating hepatocytes, and members of the Perry and

482 Pollak labs for helpful discussions. This study was funded by grants from the U.S. Public Health 
bioRxiv preprint doi: https://doi.org/10.1101/2022.03.02 482685; this version posted March 4, 2022. The copyright holder for this preprint (which was not certified by peer review) is the author/funder, who has granted bioRxiv a license to display the preprint in perpetuity. It is made available under aCC-BY-NC-ND 4.0 International license.

484 [supporting N.D.A.], T32GM136651 [supporting B.P.L.], and P30DK034989 [supporting the Yale

485 Liver Center]).

486

\section{Competing Interests}

488 The authors have no financial or non-financial competing interests related to this work. 


\section{References}

Alves TC, Befroy DE, Kibbey RG, Kahn M, Codella R, Carvalho RA, Petersen KF, Shulman GI. 2011. Regulation of hepatic fat and glucose oxidation in rats with lipid-induced hepatic insulin resistance. Hepatology 53:1175-1181. doi:https://doi.org/10.1002/hep.24170

Befroy DE, Perry RJ, Jain N, Dufour S, Cline GW, Trimmer JK, Brosnan J, Rothman DL, Petersen KF, Shulman GI. 2014. Direct assessment of hepatic mitochondrial oxidative and anaplerotic fluxes in humans using dynamic 13C magnetic resonance spectroscopy. Nat Med 20:98-102. doi:10.1038/nm.3415

Bray NL, Pimentel H, Melsted P, Pachter L. 2016. Near-optimal probabilistic RNA-seq quantification. Nat Biotechnol 34:525-527. doi:10.1038/nbt.3519

Brazma A, Parkinson H, Sarkans U, Shojatalab M, Vilo J, Abeygunawardena N, Holloway E, Kapushesky M, Kemmeren P, Lara GG, Oezcimen A, Rocca-Serra P, Sansone S-A. 2003. ArrayExpress--a public repository for microarray gene expression data the EBI. Nucleic Acids Res 31:68-71. doi:10.1093/nar/gkg091

Brown MF, Gratton TP, Stuart JeffreyA. 2007. Metabolic rate does not scale with body mass in cultured mammalian cells. American Journal of Physiology-Regulatory, Integrative and Comparative Physiology 292:R2115-R2121. doi:10.1152/ajpregu.00568.2006

Camporez JPG, Jornayvaz FR, Petersen MC, Pesta D, Guigni BA, Serr J, Zhang D, Kahn M, Samuel VT, Jurczak MJ, Shulman GI. 2013. Cellular Mechanisms by Which FGF21 Improves Insulin Sensitivity in Male Mice. Endocrinology 154:3099-3109. doi:10.1210/en.2013-1191

Chown SL, Marais E, Terblanche JS, Klok CJ, Lighton JRB, Blackburn TM. 2007. Scaling of insect metabolic rate is inconsistent with the nutrient supply network model. Functional Ecology 21:282-290. doi:10.1111/j.1365-2435.2007.01245.x

Clarke A, Johnston NM. 1999. Scaling of metabolic rate with body mass and temperature in teleost fish. Journal of Animal Ecology 68:893-905. doi:10.1046/j.13652656.1999.00337.x

Conesa A, Madrigal P, Tarazona S, Gomez-Cabrero D, Cervera A, McPherson A, Szcześniak MW, Gaffney DJ, Elo LL, Zhang X, Mortazavi A. 2016. A survey of best practices for RNA-seq data analysis. Genome Biology 17:13. doi:10.1186/s13059-016-0881-8

Darveau C-A, Hochachka PW, Roubik DW, Suarez RK. 2005. Allometric scaling of flight energetics in orchid bees: evolution of flux capacities and flux rates. Journal of Experimental Biology 208:3593-3602. doi:10.1242/jeb.01777

Darveau C-A, Suarez RK, Andrews RD, Hochachka PW. 2002. Allometric cascade as a unifying principle of body mass effects on metabolism. Nature 417:166-170. doi:10.1038/417166a

Durinck S, Spellman PT, Birney E, Huber W. 2009. Mapping identifiers for the integration of genomic datasets with the R/Bioconductor package biomaRt. Nat Protoc 4:1184-1191. doi:10.1038/nprot.2009.97

Ernest SKM, Enquist BJ, Brown JH, Charnov EL, Gillooly JF, Savage VM, White EP, Smith FA, Hadly EA, Haskell JP, Lyons SK, Maurer BA, Niklas KJ, Tiffney B. 2003. Thermodynamic and metabolic effects on the scaling of production and population energy use. Ecology Letters 6:990-995. doi:10.1046/j.1461-0248.2003.00526.x

Felig P, Wahren J. 1971. Interrelationship Between Amino Acid and Carbohydrate Metabolism During Exercise: The Glucose Alanine-Cycle In: Pernow B, Saltin B, editors. Muscle Metabolism During Exercise: Proceedings of a Karolinska Institutet Symposium Held in Stockholm, Sweden, September 6-9, 1970 Honorary Guest: E Hohwü Christensen, Advances in Experimental Medicine and Biology. Boston, MA: Springer US. pp. 205214. doi:10.1007/978-1-4613-4609-8_19 
Fenchel T, Finlay BJ. 1983. Respiration rates in heterotrophic, free-living protozoa. Microb Ecol 9:99-122. doi:10.1007/BF02015125

Gillooly JF, Brown JH, West GB, Savage VM, Charnov EL. 2001. Effects of size and temperature on metabolic rate. Science 293:2248-2251. doi:10.1126/science.1061967

Gjoni V, Basset A, Glazier DS. 2020. Temperature and predator cues interactively affect ontogenetic metabolic scaling of aquatic amphipods. Biol Lett 16:20200267. doi:10.1098/rsbl.2020.0267

Glazier DS. 2015. Body-Mass Scaling of Metabolic Rate: What are the Relative Roles of Cellular versus Systemic Effects? Biology 4:187-199. doi:10.3390/biology4010187

Glazier DS. 2008. Effects of metabolic level on the body size scaling of metabolic rate in birds and mammals. Proc Biol Sci 275:1405-1410. doi:10.1098/rspb.2008.0118

Hatton IA, Dobson AP, Storch D, Galbraith ED, Loreau M. 2019. Linking scaling laws across eukaryotes. PNAS 116:21616-21622. doi:10.1073/pnas.1900492116

Hudson LN, Isaac NJB, Reuman DC. 2013. The relationship between body mass and field metabolic rate among individual birds and mammals. J Anim Ecol 82:1009-1020. doi:10.1111/1365-2656.12086

Jansen HT, Evans Hutzenbiler B, Hapner HR, McPhee ML, Carnahan AM, Kelley JL, Saxton MW, Robbins CT. 2021. Can offsetting the energetic cost of hibernation restore an active season phenotype in grizzly bears (Ursus arctos horribilis)? J Exp Biol 224:jeb242560. doi:10.1242/jeb.242560

Jansen HT, Trojahn S, Saxton MW, Quackenbush CR, Evans Hutzenbiler BD, Nelson OL, Cornejo OE, Robbins CT, Kelley JL. 2019. Hibernation induces widespread transcriptional remodeling in metabolic tissues of the grizzly bear. Commun Biol 2:336. doi:10.1038/s42003-019-0574-4

Jassal B, Matthews L, Viteri G, Gong C, Lorente P, Fabregat A, Sidiropoulos K, Cook J, Gillespie M, Haw R, Loney F, May B, Milacic M, Rothfels K, Sevilla C, Shamovsky V, Shorser S, Varusai T, Weiser J, Wu G, Stein L, Hermjakob H, D’Eustachio P. 2020. The reactome pathway knowledgebase. Nucleic Acids Res 48:D498-D503. doi:10.1093/nar/gkz1031

Kleiber M. 1932. Body size and metabolism. Hilgardia 6:315-353.

Kolokotrones T, Van Savage, Deeds EJ, Fontana W. 2010. Curvature in metabolic scaling. Nature 464:753-756. doi:10.1038/nature08920

Krebs HA. 1950. Body size and tissue respiration. Biochimica et Biophysica Acta 4:249-269. doi:10.1016/0006-3002(50)90032-1

Kuleshov MV, Jones MR, Rouillard AD, Fernandez NF, Duan Q, Wang Z, Koplev S, Jenkins SL, Jagodnik KM, Lachmann A, McDermott MG, Monteiro CD, Gundersen GW, Ma'ayan A. 2016. Enrichr: a comprehensive gene set enrichment analysis web server 2016 update. Nucleic Acids Res 44:W90-97. doi:10.1093/nar/gkw377

Lin HV, Accili D. 2011. Hormonal Regulation of Hepatic Glucose Production in Health and Disease. Cell Metabolism 14:9-19. doi:10.1016/j.cmet.2011.06.003

Maino JL, Kearney MR. 2014. Ontogenetic and interspecific metabolic scaling in insects. Am Nat 184:695-701. doi:10.1086/678401

Makarieva Anastassia M, Gorshkov VG, Li B-L. 2005. Energetics of the smallest: do bacteria breathe at the same rate as whales? Proceedings of the Royal Society B: Biological Sciences 272:2219-2224. doi:10.1098/rspb.2005.3225

Makarieva A. M., Gorshkov VG, Li B-L. 2005. Biochemical universality of living matter and its metabolic implications. Functional Ecology 19:547-557. doi:10.1111/j.13652435.2005.01005.x

Makarieva AM, Gorshkov VG, Li B-L, Chown SL, Reich PB, Gavrilov VM. 2008. Mean massspecific metabolic rates are strikingly similar across life's major domains: Evidence for life's metabolic optimum. PNAS 105:16994-16999. doi:10.1073/pnas.0802148105 
624

625

626

627

628

629

630

631

632

633

634

635

636

637

638

639

640

Martínez-Reyes I, Chandel NS. 2020. Mitochondrial TCA cycle metabolites control physiology and disease. Nat Commun 11:102. doi:10.1038/s41467-019-13668-3

Mori S, Yamaji K, Ishida A, Prokushkin SG, Masyagina OV, Hagihara A, Hoque ATMR, Suwa R, Osawa A, Nishizono T, Ueda T, Kinjo M, Miyagi T, Kajimoto T, Koike T, Matsuura Y, Toma T, Zyryanova OA, Abaimov AP, Awaya Y, Araki MG, Kawasaki T, Chiba Y, Umari M. 2010. Mixed-power scaling of whole-plant respiration from seedlings to giant trees. PNAS 107:1447-1451. doi:10.1073/pnas.0902554107

Moses ME, Hou C, Woodruff WH, West GB, Nekola JC, Zuo W, Brown JH. 2008. Revisiting a Model of Ontogenetic Growth: Estimating Model Parameters from Theory and Data. The American Naturalist 171:632-645. doi:10.1086/587073

Perry RJ, Borders CB, Cline GW, Zhang X-M, Alves TC, Petersen KF, Rothman DL, Kibbey RG, Shulman GI. 2016. Propionate Increases Hepatic Pyruvate Cycling and Anaplerosis and Alters Mitochondrial Metabolism. J Biol Chem 291:12161-12170. doi:10.1074/jbc.M116.720631

Perry RJ, Camporez J-PG, Kursawe R, Titchenell PM, Zhang D, Perry CJ, Jurczak MJ, Abudukadier A, Han MS, Zhang X-M, Ruan H-B, Yang X, Caprio S, Kaech SM, Sul HS, Birnbaum MJ, Davis RJ, Cline GW, Petersen KF, Shulman Gl. 2015. Hepatic acetyl CoA links adipose tissue inflammation to hepatic insulin resistance and type 2 diabetes. Cell 160:745-758. doi:10.1016/j.cell.2015.01.012

Perry RJ, Peng L, Abulizi A, Kennedy L, Cline GW, Shulman GI. 2017a. Mechanism for leptin's acute insulin-independent effect to reverse diabetic ketoacidosis. J Clin Invest 127:657669. doi:10.1172/JCl88477

Perry RJ, Peng L, Cline GW, Butrico GM, Wang Y, Zhang X-M, Rothman DL, Petersen KF, Shulman Gl. 2017b. Non-invasive assessment of hepatic mitochondrial metabolism by positional isotopomer NMR tracer analysis (PINTA). Nat Commun 8:798. doi:10.1038/s41467-017-01143-w

Perry RJ, Wang Y, Cline GW, Rabin-Court A, Song JD, Dufour S, Zhang XM, Petersen KF, Shulman GI. 2018. Leptin Mediates a Glucose-Fatty Acid Cycle to Maintain Glucose Homeostasis in Starvation. Cell 172:234-248.e17. doi:10.1016/j.cell.2017.12.001

Perry RJ, Zhang D, Guerra MT, Brill AL, Goedeke L, Nasiri AR, Rabin-Court A, Wang Y, Peng L, Dufour S, Zhang Y, Zhang X-M, Butrico GM, Toussaint K, Nozaki Y, Cline GW, Petersen KF, Nathanson MH, Ehrlich BE, Shulman GI. 2020. Glucagon stimulates gluconeogenesis by INSP3R1-mediated hepatic lipolysis. Nature 579:279-283. doi:10.1038/s41586-020-2074-6

Petersen KF, Befroy DE, Dufour S, Rothman DL, Shulman GI. 2016. Assessment of Hepatic Mitochondrial Oxidation and Pyruvate Cycling in NAFLD by $13 \mathrm{C}$ Magnetic Resonance Spectroscopy. Cell Metabolism 24:167-171. doi:10.1016/j.cmet.2016.06.005

Petersen KF, Dufour S, Cline GW, Shulman GI. 2019. Regulation of hepatic mitochondrial oxidation by glucose-alanine cycling during starvation in humans. J Clin Invest 129:4671-4675. doi:10.1172/JCl129913

Petersen KF, Morino K, Alves TC, Kibbey RG, Dufour S, Sono S, Yoo PS, Cline GW, Shulman GI. 2015. Effect of aging on muscle mitochondrial substrate utilization in humans. Proc Natl Acad Sci USA 112:11330-11334. doi:10.1073/pnas.1514844112

Porter RK, Brand MD. 1995. Causes of differences in respiration rate of hepatocytes from mammals of different body mass. American Journal of Physiology-Regulatory, Integrative and Comparative Physiology 269:R1213-R1224. doi:10.1152/ajpregu.1995.269.5.R1213

Porter RK, Brand MD. 1993. Body mass dependence of $\mathrm{H}+$ leak in mitochondria and its relevance to metabolic rate. Nature 362:628-630. doi:10.1038/362628a0

Reich PB, Tjoelker MG, Machado J-L, Oleksyn J. 2006. Universal scaling of respiratory metabolism, size and nitrogen in plants. Nature 439:457-461. doi:10.1038/nature04282 
641

642

643

644

645

646

647

648

649

650

651

652

653

654

655

656

657

658

659

660

661

662

663

664

665

666

667

668

669

670

671

672

673

674

675

676

677

678

679

680

681

682

683

684

685

686

687

688

689

690

Ritchie ME, Phipson B, Wu D, Hu Y, Law CW, Shi W, Smyth GK. 2015. limma powers differential expression analyses for RNA-sequencing and microarray studies. Nucleic Acids Research 43:e47. doi:10.1093/nar/gkv007

Robinson MD, McCarthy DJ, Smyth GK. 2010. edgeR: a Bioconductor package for differential expression analysis of digital gene expression data. Bioinformatics 26:139-140. doi:10.1093/bioinformatics/btp616

Rossell S, van der Weijden CC, Kruckeberg AL, Bakker BM, Westerhoff HV. 2005. Hierarchical and metabolic regulation of glucose influx in starved Saccharomyces cerevisiae. FEMS Yeast Research 5:611-619. doi:10.1016/j.femsyr.2004.11.003

Rubalcaba JG, Verberk WCEP, Hendriks AJ, Saris B, Woods HA. 2020. Oxygen limitation may affect the temperature and size dependence of metabolism in aquatic ectotherms. Proc Natl Acad Sci U S A 117:31963-31968. doi:10.1073/pnas.2003292117

Savage VM, Allen AP, Brown JH, Gillooly JF, Herman AB, Woodruff WH, West GB. 2007. Scaling of number, size, and metabolic rate of cells with body size in mammals. PNAS 104:4718-4723. doi:10.1073/pnas.0611235104

Savage VM, Gillooly JF, Woodruff WH, West GB, Allen AP, Enquist BJ, Brown JH. 2004. The predominance of quarter-power scaling in biology. Functional Ecology 18:257-282. doi:10.1111/j.0269-8463.2004.00856.x

Schwanhäusser B, Busse D, Li N, Dittmar G, Schuchhardt J, Wolf J, Chen W, Selbach M. 2011. Global quantification of mammalian gene expression control. Nature 473:337-342. doi:10.1038/nature10098

Song JD, Alves TC, Befroy DE, Perry RJ, Mason GF, Zhang X-M, Munk A, Zhang Y, Zhang D, Cline GW, Rothman DL, Petersen KF, Shulman GI. 2020. Dissociation of Muscle Insulin Resistance from Alterations in Mitochondrial Substrate Preference. Cell Metabolism 32:726-735.e5. doi:10.1016/j.cmet.2020.09.008

Suarez RK, Moyes CD. 2012. Metabolism in the age of 'omes.' Journal of Experimental Biology 215:2351-2357. doi:10.1242/jeb.059725

Thommen A, Werner S, Frank O, Philipp J, Knittelfelder O, Quek Y, Fahmy K, Shevchenko A, Friedrich BM. n.d. Body size-dependent energy storage causes Kleiber's law scaling of the metabolic rate in planarians 29.

Tøien Ø, Blake J, Edgar DM, Grahn DA, Heller HC, Barnes BM. 2011. Hibernation in black bears: independence of metabolic suppression from body temperature. Science 331:906-909. doi:10.1126/science.1199435

Vincze O, Colchero F, Lemaître J-F, Conde DA, Pavard S, Bieuville M, Urrutia AO, Ujvari B, Boddy AM, Maley CC, Thomas F, Giraudeau M. 2022. Cancer risk across mammals. Nature 601:263-267. doi:10.1038/s41586-021-04224-5

Virtanen P, Gommers R, Oliphant TE, Haberland M, Reddy T, Cournapeau D, Burovski E, Peterson P, Weckesser W, Bright J, van der Walt SJ, Brett M, Wilson J, Millman KJ, Mayorov N, Nelson ARJ, Jones E, Kern R, Larson E, Carey CJ, Polat I, Feng Y, Moore EW, VanderPlas J, Laxalde D, Perktold J, Cimrman R, Henriksen I, Quintero EA, Harris CR, Archibald AM, Ribeiro AH, Pedregosa F, van Mulbregt P, SciPy 1.0 Contributors. 2020. SciPy 1.0: fundamental algorithms for scientific computing in Python. Nat Methods 17:261-272. doi:10.1038/s41592-019-0686-2

Waskom ML. 2021. seaborn: statistical data visualization. Journal of Open Source Software 6:3021. doi:10.21105/joss.03021

West GB, Brown JH, Enquist BJ. 1997. A General Model for the Origin of Allometric Scaling Laws in Biology. Science 276:122-126. doi:10.1126/science.276.5309.122

West GB, Woodruff WH, Brown JH. 2002. Allometric scaling of metabolic rate from molecules and mitochondria to cells and mammals. Proc Natl Acad Sci U S A 99:2473-2478. doi:10.1073/pnas.012579799 
bioRxiv preprint doi: https://doi.org/10.1101/2022 03.02 482685; this version posted March 4, 2022. The copyright holder for this preprint (which was not certified by peer review) is the author/funder, who has granted bioRxiv a license to display the preprint in perpetuity. It is made available under aCC-BY-NC-ND 4.0 International license.

691 White CR, Seymour RS. 2003. Mammalian basal metabolic rate is proportional to body

692 mass2/3. PNAS 100:4046-4049. doi:10.1073/pnas.0436428100

693

694

695

696

Williamson D, Lund $\mathrm{P}$, Krebs $\mathrm{H}$. 1967. The redox state of free nicotinamide-adenine dinucleotide in the cytoplasm and mitochondria of rat liver. Biochemical Journal 103:514-527. doi:10.1042/bj1030514 
A

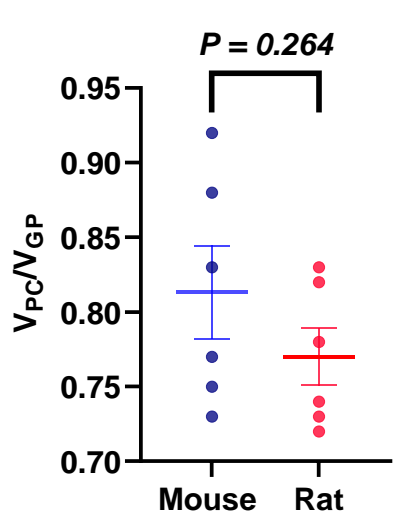

B

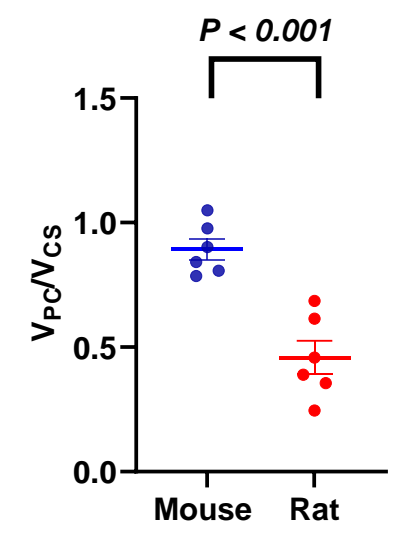

C

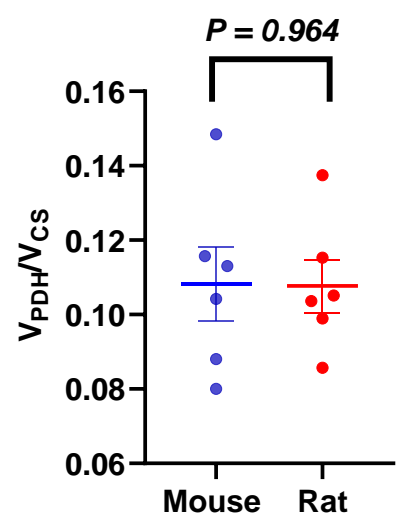

699

700

Figure S1. Flux ratios in plated hepatocytes. (A) $\mathrm{V}_{\mathrm{PC}} / \mathrm{V}_{\mathrm{GP}}$. (B) $\mathrm{V}_{\mathrm{PC}} / \mathrm{V}_{\mathrm{CS}}$. (C) $\mathrm{V}_{\mathrm{PDH}} / \mathrm{V}_{\mathrm{CS}}$.

A

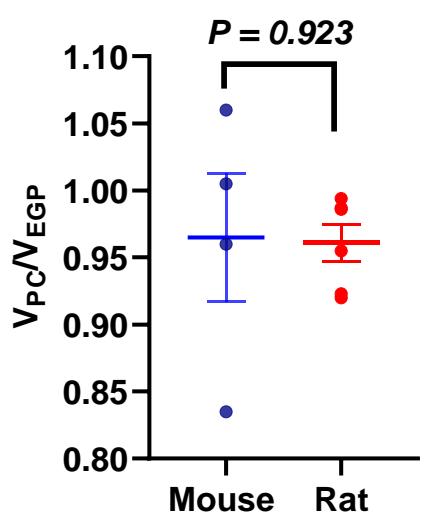

B

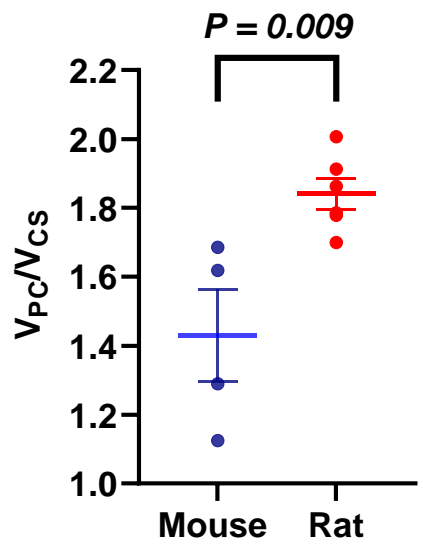

C

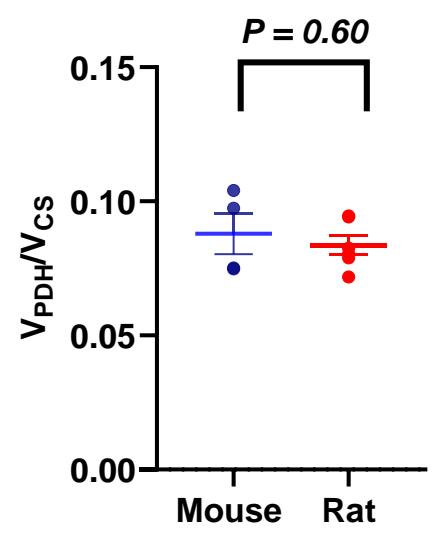

701

Figure S2. Flux ratios in vivo. (A) $\mathrm{V}_{\mathrm{PC}} / \mathrm{V}_{\mathrm{EGP}}$. (B) $\mathrm{V}_{\mathrm{PC}} / \mathrm{V}_{\mathrm{CS}}$. (C) $\mathrm{V}_{\mathrm{PDH}} / \mathrm{V}_{\mathrm{CS}}$. 


\begin{tabular}{|c|c|}
\hline Equation & Interpretation \\
\hline $\begin{array}{l}\text { 1. }{ }^{13} \mathrm{C} 4 \text { malate }= \\
\text { Total }{ }^{13} \mathrm{C} \text { malate }-{ }^{13} \mathrm{C} 1 \mathrm{C} 2 \mathrm{C} 3 \text { malate }\end{array}$ & {$\left[4-{ }^{13} \mathrm{C}\right]$ malate, equivalent to $\left[1-{ }^{13} \mathrm{C}\right]$ malate } \\
\hline $\begin{array}{l}\text { 2. }{ }^{13} \mathrm{C} 2 \mathrm{C} 3 \text { malate }= \\
\text { Total }{ }^{13} \mathrm{C} \text { malate }-2 *\left({ }^{13} \mathrm{C} 4 \text { malate }\right)\end{array}$ & Enrichment in carbons 2 and 3 of malate \\
\hline $\begin{array}{l}\text { 3. } \text { Turnover }=\left(\frac{\text { Tracer } A P E}{\text { Plasma } A P E}-1\right) * \\
\text { Infusion rate }\end{array}$ & $\begin{array}{l}\text { Whole-body endogenous glucose or } \\
\text { palmitate production }\end{array}$ \\
\hline 4. $G N G=$ Glucose turnover & Whole-body gluconeogenesis \\
\hline 5. $\frac{V_{P E P C K}}{V_{G N G}} \sim \frac{V_{P C}}{V_{G N G}}=\frac{\left[{ }^{13} C_{2}\right] \text { glucose }}{X F E^{2}}$ & $\begin{array}{l}\text { Fraction of gluconeogenesis derived from } \\
\text { pyruvate }\end{array}$ \\
\hline 6. $X F E=\frac{1}{1+\frac{\left[{ }^{13} C_{1}\right] \text { glucose }}{2 *\left[{ }^{13} C_{2}\right] \text { glucose }}}$ & Fractional triose enrichment \\
\hline $\begin{array}{l}\text { 7. } \text { Corrected }\left[{ }^{13} C_{2}\right] \text { glucose }= \\
\text { Measured }\left[{ }^{13} C_{2}\right] \text { glucose }-2 * \\
{\left[\text { C } 4 \text { C } 5 \text { C } 6-{ }^{13} C_{2}\right] \text { glucose }}\end{array}$ & $\begin{array}{l}\text { Doubly-labeled glucose arising from the } \\
\text { condensation of two singly labeled trioses, } \\
\text { correcting for doubly labeled glucose arising } \\
\text { from one doubly labeled triose condensing } \\
\text { with an unlabeled triose }\end{array}$ \\
\hline 8. $\frac{V_{P C}}{V_{C S}}=\frac{\left[5-{ }^{13} C\right] \text { glucose }}{2 *\left[4-{ }^{13} C\right] \text { glucose }}$ & $\begin{array}{l}\text { Rate of pyruvate carboxylase anaplerosis } \\
\text { relative to TCA cycle flux }\end{array}$ \\
\hline 9. $\frac{V_{P D H}}{V_{C S}}=\frac{\left[4-{ }^{13} C\right] \text { glutamate }}{\left[{ }^{13} C\right] \text { alanine }}$ & $\begin{array}{l}\text { Fractional contribution of glucose to the TCA } \\
\text { cycle }\end{array}$ \\
\hline 10. $V_{P C}=\frac{V_{P C}}{V_{G N G}} * V_{G N G}$ & $\begin{array}{l}\text { Absolute rate of gluconeogenesis from } \\
\text { pyruvate }\end{array}$ \\
\hline 11. $V_{C S}=\left(\frac{V_{P C}}{V_{C S}}\right)^{-1} * V_{P C}$ & Absolute TCA cycle flux \\
\hline 12. $V_{P D H}=\frac{V_{P D H}}{V_{C S}} * V_{C S}$ & $\begin{array}{c}\text { Absolute rate of glycolytic carbon entry into } \\
\text { the TCA cycle }\end{array}$ \\
\hline 13. $V_{F A O}=V_{C S}-V_{P D H}$ & $\begin{array}{l}\text { Absolute rate of entry of carbons from } \\
\text { oxidized fatty acids into the TCA cycle }\end{array}$ \\
\hline
\end{tabular}

Table S1. Flux ratios and absolute rates measured in mice infused with $\left[3^{13} \mathrm{C}\right]$ lactate. APE indicates the atom percent enrichment (in animals infused with ${ }^{13} \mathrm{C}$ tracer), TCA denotes the tricarboxylic acid cycle, and GNG denotes gluconeogenesis. By convention, $\mathrm{V}_{\mathrm{a}}$ represents the flux through pathway $a$. 